\title{
Effects of different fertilization practices on the glucose, fructose, sucrose, taste and texture of carrot
}

\author{
AINO-MAIJA EVERS \\ Kemira Oy, Espoo Research Centre, Luoteisrinne 2, \\ SF-02270 Espoo, Finland
}

\begin{abstract}
The effects of different fertilization practices on the glucose, fructose, sucrose, taste and texture of carrot cv. Nantes Duke Notabene 370 Sv were studied in field experiments carried out in southern Finland in 1985 and 1986. The effects of unirrigated and irrigated placement and broadcast fertilization, NPK fertirrigations without basic fertilization, NPK fertirrigations with NPK basic fertilization, and PK placement with $\mathrm{N}$ fertirrigations were compared. Further, the effects of single application were compared with those of split applications. Sugar analyses were made by high performance liquid chromatography, and sensory evaluations were performed for taste and texture. The results were analysed by contrast analysis.

In 1985, fertilization and fertilization practices had no effects on sugar contents. In 1986, the unfertilized treatments had a tendency to yield higher glucose and fructose, and thus also total sugar contents than did the fertilized treatments on the average. Placement fertilization had a tendency to increase the glucose content as compared to NPK fertirrigations. No significant differences or tendencies were found in sucrose content.

The glucose and fructose contents were higher in 1985 than in 1986. The sucrose content was mainly opposite, being higher in 1986 . Weather conditions were more favourable for photosynthesis in 1986 than in 1985 . The mean total sugar content in fresh weight was $7.8 \%$ in 1985 and $6.7 \%$ in 1986. Indicative results of taste and texture are presented. The sugar content in organically cultivated carrots did not differ from that of conventionally grown carrots, but the taste was worse.
\end{abstract}

Index words: fertilization practices, carrot, quality, sugars, sensory evaluation, taste, texture, organic culture

\section{Introduction}

The sugar contents and flavour of carrot (Daucus carota L.) are influenced by genotype and environment (SimON et al. $1980 \mathrm{a}, 1980 \mathrm{~b}$, 1982). Many researchers have reported that year and location have a considerable effect on both overall quality and the sugar contents of carrots (HÄrdH 1975, Balvoll et al. 1976, Martens 1985).

The literature contains contradictory results concerning the influence of fertilization on the 
sugar contents of carrots. BARNES (1936) reported that increasing nitrogen levels increases the amount of glucose, but at the same time he found decreasing sucrose amounts. $H_{A B B E N}$ (1972) reported that increasing nitrogen levels increases the amount of reducing sugars (glucose and fructose) but do not affect the sucrose content. According to Dragland (1978), an increasing amount of nitrogen does not effect the glucose content, but decrease the sucrose content of carrots. In NILsson's (1979) study, the content of sugars (glucose, fructose, sucrose) in carrots is unaffected by either the type of fertilizer (organic or inorganic) or the amount of fertilizer applied. Barnes (1936) reported that increasing phosphorus levels increases the amount of sucrose but do not affect the glucose level. Potassium has been noted to decrease the total sugar content and the amount of reducing sugars, and to increase the sucrose content (HabBen 1972). On the other hand, Gallagher (1966) reported that potassium has no effect on the sugar contents of carrots.

In a review Simon (1985) lists the following components affecting carrot flavour; the free sugars (glucose, fructose, sucrose), which contribute to sweetness; volatile mono- and sesquiterpenoids, which contribute harshness and carrot flavour; 2-nonenal, which imparts cooked flavour; "iso-cumarin" and other phenolic compounds, which impart bitterness; 2-methoxy-3-butylpyrazine, which contributes to carrot aroma; free amino acids, which contribute to delicate flavour; and ionones, which impart floral off-flavour. The importance of texture to carrot sensory quality has also been noted.

Only a few studies have been published concerning the effects of fertilization practices or split application on the sugar contents and flavour of carrots. The aim of the present study is to examine the effect of unirrigated and irrigated placement and broadcast fertilization, NPK fertirrigations without basic fertilization, NPK fertirrigations with NPK basic fertilization, and $\mathrm{PK}$ placement with $\mathrm{N}$ fertirrigations on the glucose, fructose and sucrose content and on the taste and texture of carrots.

\section{Material and methods}

The field experiments were conducted in Vihti, at the Kotkaniemi experimental farm of Kemira Oy (southern Finland, $60^{\circ} 22^{\prime} \mathrm{N}$, $24^{\circ} 22^{\prime} \mathrm{E}$ ) during the growing seasons of 1985 and 1986. Carrot cv. Nantes Duke Notabene $370 \mathrm{~Sv}$ was grown consistently as reported in Evers (1988). The fertilizer treatments and macronutrient amounts are presented in $\mathrm{Ta}$ ble 1. The field experiment was arranged by completely randomized block design, with four blocks, ten treatments and $25 \mathrm{~m}^{2}$ plots. Samples for analysis were collected from two blocks in 1985 and from four blocks in 1986. The differences between treatments were studied statistically by contrast analysis and correlations between parameters were calculated (Steel \& Torrie 1980).

\section{Sugar analyses}

Carrot samples for glucose, fructose, sucrose analyses and for sensory evaluation of taste and texture were collected at harvest, on 30th September 1985 and 6th October 1986. The sugars mentioned above were determined by high performance liquid chromatography (HPLC) on a bonded aminopropylsilica stationary phase with refractive index (RI) detection (Schwarzenbach 1976). 60 grams carrot tissue (hypocotyl and root tip omitted) was grated and mixed with acetonitril water mixture (1:1), crushed in a blender, stirred for 10 minutes, filtered and analyzed by HPLC. The total sugar content given in the Results were calculated as the sum of glucose, fructose and sucrose. The weighed value of the sweetness of sugars was also calculated. The relative sweetness of glucose, fructose and sucrose depends on temperature and acidity (HyvönEn et al. 1978). When the sweetness of sucrose is considered to be 100 at room temperature, the relative sweetness of glucose is 70 , and that of fructose 120 (Hyvönen et al. 1978, Kelm 1985). 
Table 1. The fertilization treatments and the total amounts of nutrients and irrigation water.

\begin{tabular}{|c|c|c|c|c|c|}
\hline \multirow[t]{2}{*}{ Treatment } & \multirow[t]{2}{*}{$\begin{array}{l}\text { Number and time } \\
\text { of fertilizer } \\
\text { applications }\end{array}$} & \multicolumn{3}{|c|}{$\begin{array}{c}\text { Macronutrient } \\
\text { amounts in } 1986^{3} \\
\mathrm{~kg} / \mathrm{ha}\end{array}$} & \multirow{2}{*}{$\begin{array}{l}\text { Irrigation water } \\
\text { amounts in } \\
1985 \text { and } 1986 \\
\text { mm }\end{array}$} \\
\hline & & $\mathrm{N}$ & $\mathrm{P}$ & K & \\
\hline \multicolumn{6}{|l|}{ Unfertilized } \\
\hline Unirrigated & 0 & 0 & 0 & 0 & 0 \\
\hline Irrigation & 0 & 0 & 0 & 0 & $3 \times 10$ \\
\hline \multicolumn{6}{|l|}{ NPK placement } \\
\hline Unirrigated & 1 before sowing & 80 & 35 & 133 & 0 \\
\hline Irrigation & 1 before sowing & 80 & 35 & 133 & $3 \times 10$ \\
\hline \multicolumn{6}{|l|}{ NPK broadcast } \\
\hline Unirrigated & 1 before sowing & 80 & 35 & 133 & 0 \\
\hline Irrigation & 1 before sowing & 80 & 35 & 133 & $3 \times 10$ \\
\hline \multicolumn{6}{|l|}{ NPK fertirrigations } \\
\hline No basic & 3 during season & 80 & 29 & 160 & $3 \times 10$ \\
\hline Half the basic ${ }^{\prime}$ & $\begin{array}{l}1 \text { before sowing and } \\
3 \text { during season }\end{array}$ & 80 & 32 & 142 & $3 \times 10$ \\
\hline \multicolumn{6}{|l|}{ PK placement ${ }^{2}$} \\
\hline $3 \mathrm{~N}-$ fertirrigations & $\begin{array}{l}1 \text { before sowing and } \\
3 \text { during season }\end{array}$ & 81 & 56 & 133 & $3 \times 10$ \\
\hline $4 \mathrm{~N}$-fertirrigations & $\begin{array}{l}1 \text { before sowing and } \\
4 \text { during season }\end{array}$ & 155 & 56 & 133 & $4 \times 10$ \\
\hline
\end{tabular}

' Half of the nutrients were given in basic placement fertilization and half in NPK fertirrigations.

2 Phosphorus and potassium were given in basic placement fertilization and nitrogen in fertirrigations.

${ }^{3}$ The nutrient amounts were $30 \%$ higher in 1985 than 1986.

\section{Taste and texture determinations}

The sensory evaluation was performed at the Technical Research Centre of Finland, Food Research Laboratory. Ten trained tasters evaluated the taste and texture of carrot samples, in randomized order. They gave their evaluations on numerical and verbal nine-degree Karlsruhe quality scales. Each taster evaluated two carrots per treatment, four treatments at a time. At each session, carrots from unfertilized and unirrigated treatment were present as a comparison sample; thus three evaluation sessions were needed. Because the comparison sample was given somewhat different scores at each of three evaluation sessions, the scores of the second and third evaluation sessions were corrected. This was done by multiplying the scores of each taster and each treatment with the quotient comparison sample mean for the first evaluation session/comparison sample mean for the evaluation session in question. Because the residuals of taste and texture grades fol- lowed a normal distribution, it was possible to use parametrical tests for statistical analysis. The data were analyzed statistically by contrast analysis.

\section{Organically cultivated carrots}

In 1986, carrots were also grown on two organically cultivated fields in central Finland (in Varkaus and Rantasalmi). The same seed material was used, but the geographical situation and soil conditions were different. These samples were not statistically compared to fertilizer treatments.

\section{Results}

\section{Sugar contents}

The glucose and fructose contents were higher in 1985 than in 1986 (Table 2). The sucrose content was mainly opposite, being higher in 1986. Placement fertilized treatment, 


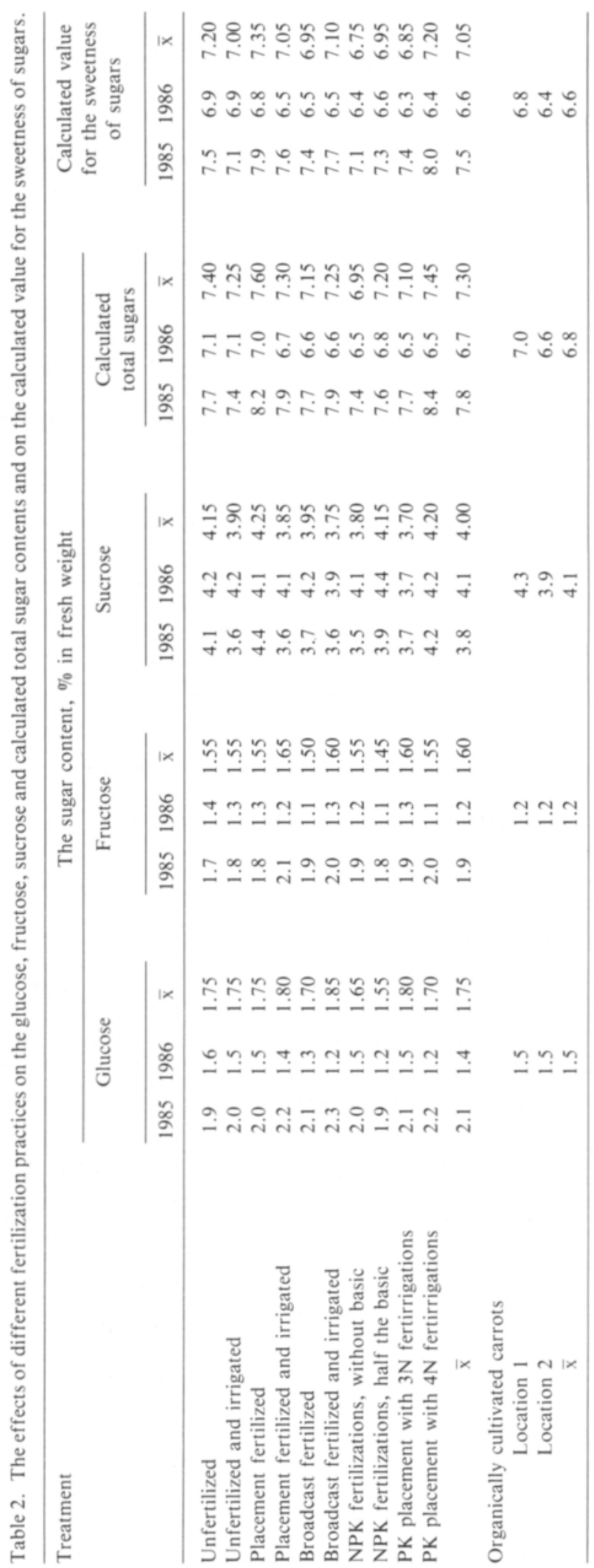


however, yielded a higher sucrose content in 1985 than in 1986, and PK placement with 3 or $4 \mathrm{~N}$ fertirrigations yielded a similar sucrose content in the two years (Table 2). Both the calculated total sugars and the calculated value for the sweetness of sugars were higher in 1985 than in 1986 (Table 2).

In 1985, no statistically significant differences were found between fertilized and unfertilized treatments or between fertilization practices. Irrigation, nitrogen amount, placement of NPK or PK fertilizer, fertirrigations or split applications did not affect the sugar contents.

In 1986, the unfertilized treatments had a tendency to yield higher glucose and fructose contents than did the fertilized treatments on the average $(\mathrm{p}<0.08)$. Placement fertilization had a tendency to increase the glucose con- tent as compared to NPK fertirrigations without or with basic fertilization $(\mathrm{p}<0.1)$. No significant differences or tendencies were found in sucrose content. Unfertilized treatments yielded a higher total sugar content and a higher calculated value for the sweetness of sugars than did fertilized treatments $(p=$ $\left.0.03^{*}\right)$, but there were no differences between fertilization practices.

\section{Taste}

Fertilization, irrigation or $\mathrm{N}$ amount did not affect taste in 1985 or 1986 as compared to unfertilized, unirrigated or treatments with high amounts of $\mathrm{N}$, respectively. But in both years, NPK fertirrigations without basic fertilization produced better taste than did placement fertilization $\left(\mathrm{p}<0.04^{*}\right)$ (Fig. 1).

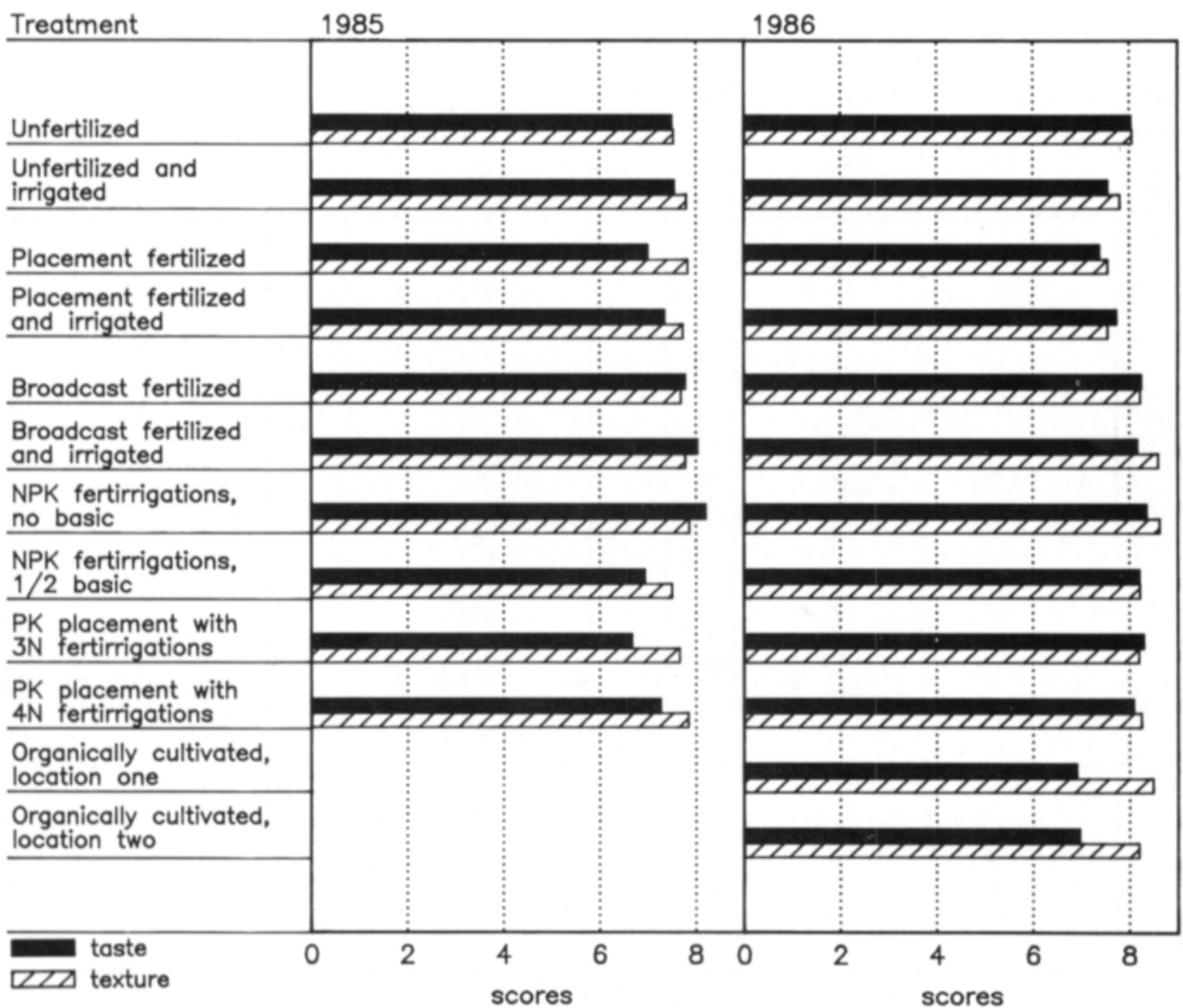

Fig. 1. The effect of different fertilization practices on the taste and texture of carrot in 1985 and 1986. 
In 1985, broadcast fertilizations and NPK fertirrigations without basic fertilization produced better taste than did PK placement with $\mathrm{N}$ fertirrigations $\left(\mathrm{p}<0.02^{*}\right)$. When $\mathrm{P}$ and $\mathrm{K}$ were not given by placement technique, a significantly better taste was obtained than when $\mathrm{P}$ and $\mathrm{K}$ were given by placement technique $\left(\mathrm{p}<0.003^{* *}\right)$ (Fig. 1).

In 1986, broadcast fertilization $\left(\mathrm{p}=0.02^{*}\right)$, split application $\left(\mathrm{p}<0.007^{* *}\right)$, NPK fertirrigations without or with basic fertilization $\left(\mathrm{p}=0.01^{*}\right)$ and $\mathrm{PK}$ placement with $\mathrm{N}$ fertirrigations $\left(\mathrm{p}<0.03^{*}\right)$ produced better taste than did placement fertilization (Fig. 1).

\section{Texture}

No significant differences between fertilized and unfertilized treatments or between fertilization practices were found in 1985 .

In 1986, NPK fertirrigations without basic fertilization produced better texture than did placement fertilization $\left(\mathrm{p}<0.002^{* *}\right)$, single application $\left(\mathrm{p}<0.04^{*}\right)$ or unirrigated single
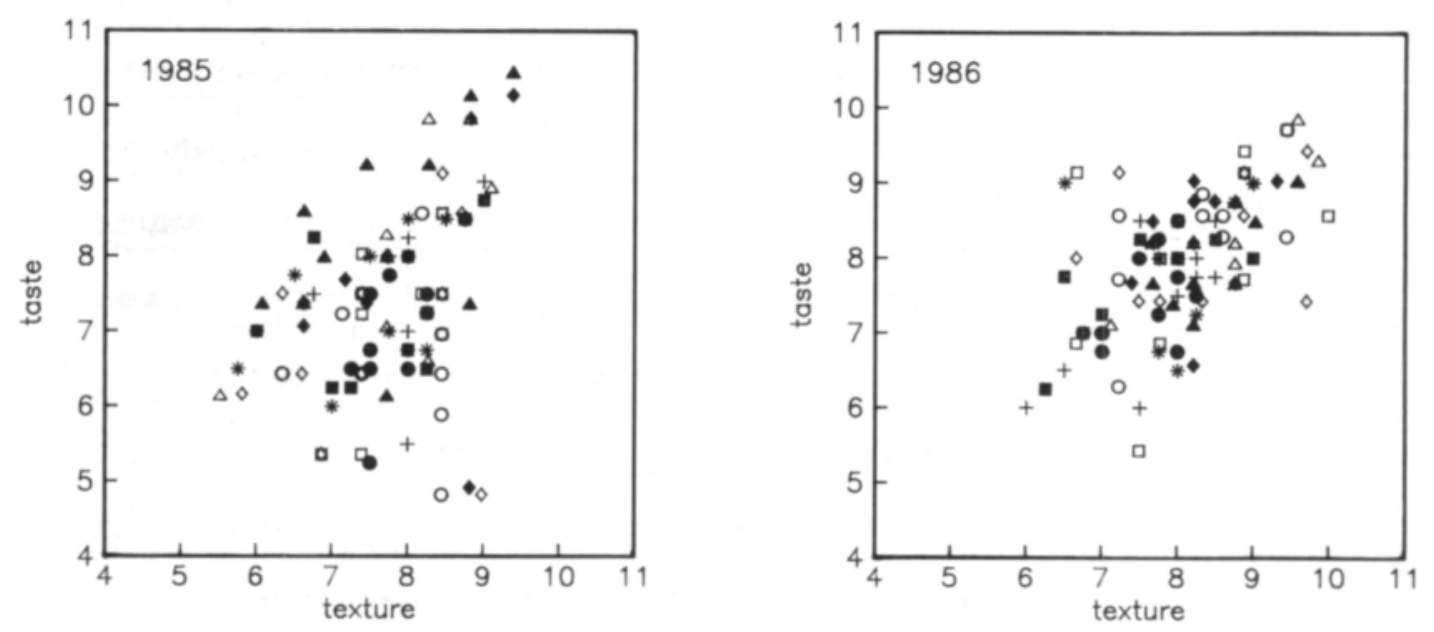

application $\left(\mathrm{p}<0.03^{*}\right)$ (Fig. 1). Irrigation did not affect texture as compared to unirrigated treatments. Broadcast fertilization $(p=$ $\left.0.002^{* *}\right)$, split application $\left(\mathrm{p}=0.001^{* *}\right)$, NPK fertirrigations without or with basic fertilization $\left(\mathrm{p}<0.002^{* *}\right)$ and $\mathrm{PK}$ placement with $\mathrm{N}$ fertirrigations $\left(\mathrm{p}<0.02^{*}\right)$ produced better texture than did placement fertilization. When $\mathrm{P}$ and $\mathrm{K}$ were not given by placement technique, a better texture was obtained than when $\mathrm{P}$ and $\mathrm{K}$ were given by placement technique $(\mathrm{p}<$ $0,005^{* *}$ ) (Fig. 1).

The taste and texture scores given by ten tasters were plotted individually for all fertilization treatments (Fig. 2). The range of variation was great for each fertilization treatment, i.e. ten tasters gave very different scores for the same fertilization treatment.

\section{Correlations between parameters}

The glucose and fructose contents, and the sucrose and total sugar contents, correlated positively in both years (Table 3 ). Further, in $\triangle$ NPK fertirrigations, no basic

- NPK fertirrigations, $1 / 2$ basic

- PK placement with $3 \mathrm{~N}$ fertirrigations

ㅁ PK placement with $4 \mathrm{~N}$ fertirrigations

- Placement fertilized and irrigated

- Broadcast fertilized

- Broadcast fertilized and irrigated

Fig. 2. The effect of different fertilization practices on the taste and texture of carrot. The scores given by ten tasters are plotted individually. 
Table 3. The correlation coefficients between glucose, fructose, sucrose, total sugars, taste and texture in 1985 and 1986.

\begin{tabular}{|c|c|c|c|c|c|c|}
\hline & Glucose & Fructose & Sucrose & $\begin{array}{c}\text { Total } \\
\text { sugars }\end{array}$ & Taste & Texture \\
\hline \multicolumn{7}{|l|}{1985} \\
\hline Iucose & 1 & $0.84 * 1$ & n.s. & n.s. & n.s. & n.s. \\
\hline Fructose & & 1 & n.s. & n.s. & n.s. & n.s. \\
\hline Sucrose & & & 1 & $0.87^{*}$ & n.s. & n.s. \\
\hline Total sugars & & & & 1 & n.s. & n.s. \\
\hline Taste & & & & & 1 & n.s. \\
\hline Texture & & & & & & 1 \\
\hline \multicolumn{7}{|l|}{1986} \\
\hline Glucose & 1 & $0.97^{* * *}$ & $-0.48^{* *}$ & $0.37^{*}$ & n.s. & n.s. \\
\hline Fructose & & 1 & $-0.52^{* * *}$ & $0.32^{*}$ & n.s. & n.s. \\
\hline Sucrose & & & 1 & $0.63^{* * *}$ & n.s. & n.s. \\
\hline Total sugars & & & & 1 & a.s. & n.s. \\
\hline Taste & & & & & 1 & $0.51^{* * *}$ \\
\hline Texture & & & & & & 1 \\
\hline \multicolumn{7}{|c|}{ significant at the $5 \%$ level } \\
\hline ** signific & $1 \%$ level & & & & & \\
\hline$* * *$ signific & $0.1 \%$ level & & & & & \\
\hline
\end{tabular}

1986 the glucose and fructose contents correlated negatively with the sucrose content, the glucose and fructose contents correlated positively with total sugars, and taste correlated positively with texture (Table 3 ).

\section{Carrots from organic cultivation}

The glucose, fructose, sucrose, total sugar contents and the calculated value for the sweetness of sugars were on the same level in organically cultivated carrots as in the carrots grown during the fertilization experiment (Table 2 ). The organically cultivated carrots did not taste good (Fig. 1).

\section{Discussion}

\section{Sugar contents}

Simon et ai. (1980 a, 1980 b, 1982) demonstrated that there is significant genetic and environmental variation for carrot sugar quantities. Sucrose was influenced most by genotype (Simon et al. 1982). In the present study, neither fertilization (as compared to unfertilized treatments) nor fertilization practices af- fected the sucrose content at all in either year. In 1986, unfertilized treatments had a tendency to yield higher glucose and fructose contents and a higher total sugar content than did fertilized treatments on the average.

The glucose, fructose and total sugar contents were higher in 1985 than in 1986. With a few exceptions, the sucrose content was higher in 1986. The weather was more favourable in 1986 than in 1985; both the mean day temperature and the number of sunshine hours in June and July were higher in 1986 than in 1985 (Evers 1988). Yield and dry matter contents were higher in 1986 than in 1985 (Evers 1988). Thus the glucose, fructose and total sugar contents seemed to be higher in the unfavourable year of 1985 and in unfertilized treatments as compared to the more favourable year of 1986 and to fertilized treatments. It is obvious that more photosynthates were produced in the more favourable year of 1986 and in fertilized treatments, but that greater amounts of photosynthates were used for phytomass production, leaving less sugars to fill the storage cells. Consequently the glucose, fructose and total sugar contents are hypothesized to be related to growth. 
In the present study, the total sugar content for all treatments was on the average $7.8 \%$ of fresh weight in 1985 and $6.7 \%$ in 1986 . These values were higher than reported by Habben (1972), Dragland (1978) and Bajaj et al. (1980), and on same level as those reported by Phan \& Hsu (1973), Fritz \& HabBen (1975), and Nilsson $(1979,1987)$. The reasons for the different total sugar levels reported in different studies are probably both genetic and environmental, and they ought to be examined in relation to growth.

The superiority order of the treatments was similar when the calculated total sugar value was compared with the calculated value for the sweetness of sugars. This indicates that all treatments produced roughly similar proportional amounts of glucose, fructose and sucrose.

\section{Taste and texture}

The flavour of raw carrots is influenced by genotype and environment (SIMON et al. 1982). Sugars and volatile terpenoids are the two major components of carrot flavour (Freeman \& Simon 1983), but carrot aroma is very complex, and is affected by many compounds (Simon 1985). In the present study, in both years, NPK fertirrigations without basic fertilization produced better taste than did placement fertilization. On the other hand placement fertilization had a tendency to increase the glucose content as compared to NPK fertirrigations, but no correlation was found between glucose content and taste. Because no earlier research could be found on this subject, it would be a very interesting topic of further study, using different varieties and different environmental conditions. Two aspects are interesting; why did NPK fertirrigations without basic fertilization have a favourable effect on taste, and why did placement fertilization have a negative effect on taste?

The taste and texture results obtained in this study should be considered to be indicative only, because the taste panel evaluated ten samples, one for each treatment; thus there were no replicates. The taste panel comprised only ten people, and each taster evaluated two carrots; thus 20 carrots were evaluated per treatment. The range of variation in taste and texture scores between individual tasters was great. This may be due to differences between tasters or due to great variation between individual carrots. The variation would have been smaller had all tasters evaluated carrot pieces cut from the same carrots, but in this case less carrots could have been studied. If there had been a great variation between individual carrots, it would not have been noticed.

\section{Carrots from organic cultivation}

The sugar content of organically cultivated carrots was on the same level as that of the carrots grown during the fertilization experiment. This is in agreement with the fact that sugar content is, to a large extent, genetically controlled. Environmental variation is not as remarkable as genetic variation (SIMON et al. 1982). The negative results of the sensory evaluation should give rise to closer study, performed by analyzing the aroma components of organically cultivated carrots.

\section{In conclusion}

No statistically significant differences (at the level of $\mathrm{p} \leq 0.05$ ) in sugar contents were found between fertilization practices. This is in agreement with the study of SIMON et al. (1982), where genotypic variation was highly significant in reducing sugars, sucrose, and total sugars, the influence of soil and climate being slight as compared to the genetic influence. In the present investigation, in 1986, unfertilized treatments produced a higher total sugar content than did fertilized treatments, on the average, and the total sugar content was higher in less favourable year of 1985 than in 1986 , on the average, for all treatments. Thus it can be hypothesized that because the total phytomass production was greater in fertilized treatments and in 1986 (Evers 1988); conse- 
quently more photosynthates were used for phytomass production, leaving less sugars for the storage organ. The taste and texture results obtained in this study should be considered to be indicative only.

\section{References}

Bajaj, K.L., Kaur, G. \& Sukhija, B.S. 1980. Chemical composition and some plant characteristics in relation to quality of some promising cultivars of carrot (Daucus carota L.). Qual. Plant. Pl. Foods Hum. Nutr. 30: 97-107.

Balvoll, G., Apeland, J. \& Auranaune, J. 1976. Kjemisk samansetnad og organoleptisk kvalitet hjå gulrot frå sør- og nord-Noreg. Forskn. Förs. Landbr. 56: $327-337$.

BARNES, W.C. 1936. Effects of some environmental factors on growth and color of carrots. Cornell Univ. Agric. Exp. Stn. Mem. 186: 2-36.

Dragland, S. 1978. Nitrogen- og vassbehov hos gulrot. Forskn. Förs. Landbr. 29: 139-159.

Evers, A-M. 1988 Effects of different fertilization practices on the growth, yield and dry matter content of carrot. J. Agric. Sci. Finl. 60: 135-152.

Freeman, R.E. \& Simon, P.W. 1983. Evidence for simple genetic control of sugar type in carrot (Daucus carota L.). J. Amer. Soc. Hort. Sci. 108: 50-54.

FrITZ, D. \& HABBEN, J. 1975. Determination of ripeness of carrots (Daucus carota L.). Acta Hort. 52: 231-238.

Gallagher, P.A. 1966. The effect of potassium on yield and quality of carrots. Proc. 8. Intern. Potash Inst. Congr. Brüssel. p. 257-263.

Habsen, J. 1972. Einfluss von Düngung und Standort auf die Bildung wertgebender Inhaltsstoffe in Möhren (Daucus carota L.). Diss. Techn. Univ. München.

HÁrdh, J.E. 1975. Der einfluss der umwelt nördlicher breitengrade auf die qualităt der gemüse. Qual. Plant. 25: $43-56$.

Hyvonen, L., Kurkela, R., Koivistoinen, P. \& AlaKulsu, M-L. 1978. The relative sweetness of fructose, glucose and xylitol in acid solutions at different temperatures. Lebensm. Wiss. Technol. 11: 11-14.

KELM, W. 1985. Einsatz vom zuckersorten, zuckerarten und künstlichen süßstoffen für alkoholfreie er-
Acknowledgements. My thanks are due to Ms. Oili Uusitalo for her excellent technical assistance with the experiments and sugar analyses and to Börje Björkqvist, M.Sc., for his expertise in sugar analysis. I am grateful to the Academy of Finland and to Kemira Oy for financial support.

frischungsgetränke. Getränkeindustrie 39: 13-18.

Martens, M., Rosenfeld, H.J. \& Russwurm, H., Jr. 1985. Predicting sensory quality of carrots from chemical, physical and agronomical variables: a multivariate study. Acta Agric. Scand. 35: 407-420.

Nıısson, T. 1979. Avkastning, lagringsförmåga, kvalitet och kemisk sammansăttning hos morot, vitkål och purjo vid konventionell och organisk gödsling. Inst. Trädg. Vet. Rapp. 7: 3-52.

- 1987. Growth and chemical composition of carrots as influenced by the time of sowing and harvest. J. Agric. Sci. Camb. 108: 459-468.

Phan, C.T. \& Hsu, H. 1973. Physical and chemical changes occuring in the carrot root during growth. Can. J. Pl. Sci. 53: 629-634.

SChWARZEnBACH, R. 1976. A chemically bonded stationary phase for carbohydrate analysis in liquid chromatography. J. Chromatogr. 117: 206-210.

Simon, P.W. 1985. Carrot flavor: effects of genotype, growing conditions, storage and processing. In: "Evaluation of quality of fruits and vegetables". (Ed. H.E. Pattee), p. 315-328. Westport, Connecticut.

Simon, P.W., Peterson, C.E. \& Lindsay, R.C. 1980 a. Genetic and environmental influences on carrot flavor. J. Amer. Soc. Hort. Sci. 105: 416-420.

-, Peterson, C.E. \& Lindsay, R.C. 1980 b. Correlations between sensory and objective parameters of carrot flavor. J. Agric. Food. Chem. 28: 559-562.

-, Peterson, C.E. \& Lindsay, R.C. 1982. Genotype, soil and climate effects on sensory and objective components of carrot flavor. J. Amer. Soc. Hort. Sci. 107: 644-648.

Steel, R.G.D. \& Torrie, J.H. 1980. Principles and procedures of statistics. A biometrical approach. 633 p. 2nd Ed. Tokyo.

Ms received March 16, 89 


\section{SELOSTUS}

\section{Lannoitusmenetelmien vaikutus porkkanan glukoosi-, fruktoosi- ja sakkaroosi- pitoisuuksiin sekä makuun ja rakenteeseen}

\author{
Aino-Maija Evers \\ Kemira Oy, Espoon tutkimuskeskus \\ Luoteisrinne 2, 02270 Espoo
}

Eri lannoitusmenetelmien vaikutusta porkkanan 'Nantes Duke Notabene 370 Sv' sokeripitoisuuksiin sekä makuun ja rakenteeseen tutkittiin vuosina 1985 ja 1986 . Kenttäkokeissa Kotkaniemen koetilalla Vihdissä oli vertailtavina lannoitusmenetelminä sijoitus- ja pintalannoitus (ilman kastelua ja kastelun kera), NPK kastelulannoitus ja NPK kastelulannoitus, jossa puolet ravinteista annettiin sijoittaen keväällä, sekä koejäsen, jossa $\mathrm{P}$ ja $\mathrm{K}$ annettiin sijoittaen keväällä ja $\mathrm{N}$ kastelulannoituksena kasvukaudella. Kokeessa verrattiin myös ravinteiden kertalevitystä jaksotettuun ravinteiden antoon. Näytteet sokerimäärityksiin ja maun ja rakenteen aistinvaraiseen arviointiin kerăttiin sadonkorjuun yhteydessä. Tulokset analysoitiin tilastollisesti kontrastianalyysillä, ja parametrien väliset korrelaatiot laskettiin.

Lannoitus (verrattuna lannoittamattomaan) ja lannoitustavat eivăt vaikuttaneet lainkaan sakkaroosipitoisuuteen kumpanakaan vuonna. Sakkaroosipitoisuus oli korkeampi kasvuoloiltaan suotuisampana vuonna 1986. Sen sijaan glukoosi-, fruktoosi- ja kokonaissokeripitoisuudet olivat korkeammat epäedullisempana vuonna 1985 kuin vuonna 1986. Glukoosi- ja fruktoosipitoisuudet olivat suuntaa-antavasti korkeammat $(\mathrm{p}<0.08)$ ja kokonaissokeripitoisuus oli korkeampi ( $\mathrm{p}=0.03$ ) vuonna 1986 lannoittamattomissa koejäsenissä kuin lannoitetuissa koejäsenissä. Koska aiemmassa tutkimuksessa (Evers 1988) on todettu, että kokonaisfytomassan tuotto oli suurempi 1986, tässä tutkimuksessa päädyttiin hypoteesiin, että porkkanan sokeripitoisuutta tulee tarkastella suhteessa kasvuun. Edullisissa kasvuoloissa yhteyttämistuotteita muodotuu enemmän, mutta koska huomattava osa niistả kuluu fytomassan tuottoon, jảả văhemmän yhteyttãmistuotteita eli sokereita sellaisenaan varastoelimeen. Kokonaissokeripitoisuudet koko aineiston keskiarvoina olivat $7.8 \%$ ja $6.7 \%$ vuosina 1985 ja 1986 . Aistinvaraisen arvioinnin suuntaa-antavat tulokset osoittivat, että NPKkastelulannoituksen saaneiden porkkanoiden maku oli kumpanakin vuonna parempi kuin sijoituslannoituksen saaneissa porkkanoissa, mutta koejäsenten văliset erot olivat pienet. Kahden orgaanisesti viljellyn havaintoaineiston porkkanoiden sokeripitoisuudet ja rakenne olivat samansuuruiset kuin vastaavat arvot lannoituskokeessa, mutta orgaanisesti viljellyt porkkanat eivät maistuneet yhtả hyvältä. 